\title{
98. 腹腔鏡下の各種卵管不妊術式とその比較
}

\author{
(鳥取大学医学部産科婦人科学教室)
}

岩 浅 義 彦

永久不妊法は家族計画にとって重要な意義を有 しており，従来日本では腹式または腟式の卵管不 妊手術が主流を占め現在に至っている。これらの 方法では手術侵襲就よび皮膚切開も大きく，手術 時間や入院日数が長いため本術式の施行が著しく 妨げられている.

一方米国 では 1970 年以来腹腔鏡の発達ととも に腹腔鏡下の卵管不妊手術が主流となり，毎年 20 万人以上の女性がこの手術を受けている，腹腔鏡 下の卵管不妊手術後には, 双極性卵管凝固法, シ リコンバンド法, スプリングクリップ法等があり, 当教室およびその関連病院にてこれら術式を施行 して好成績を収めてきたので，各術式についての 方法, 利点, 合併症, 成績について報告する.

1) 腹腔鏡下の不妊手術の 適応および禁忌: 適 応は日本母性保護医協会の揭げる項目に該当する 者. 禁忌は高度の心, 肺, 肝, 腎疾患がある者护 よび腹膜炎の現在または既往歴があるものなどで ある。

2 ）実施手技：浣腸後前投薬を投与し，NLA 麻 酔下にて人工気腹を人工気腹器を使用して, $\mathrm{CO}_{2}$ を約 $3 \sim 41$ 腹腔内に注入する. その後套管針およ び卵管鉗子または凝固鉗子が附属した腹空鏡を挿
入する，子宮内カニューレを装着し，各種手技を やりやすくする，各種手技終了後，腹腔鏡および 外套管の抜去を行う。最近我々はこれら術式をビ デオカメラに接続し，テレビモニターを見ながら 各種術式を行っている.

3）合併症：椂々な合併症が 本術式に随伴する が，乙かし注意深く施行すれば皆無にする事が可 能であり, 我々の合併症では現在のところ創部感 染症のみである。

4）成績：我々は現在まで双極性電極法を 209 例, シリコンバンド法 92 例, スプリングクリップ 法(Hulka クリップ法)を 3 例に行い, 術後の妊娠 は皆無である。

5）各種術式の比較：双極性凝固法では骨盤内 臓器の火傷損傷が起りやすく, また卵管凝固が不 十分になりやすいので，最低 2 個所凝固する必要 がある。 シリコンバンド法では装着鉗子により, 卵管問題や卵管の損傷の危険とシリコンバンドに よる卵管の締めつけにより術後疼痛を訴えやす い. スプリングクリップ法では大きな異物が腹腔 内に残存するため易感染性および卵管装着のため の術後疼痛が存在する. 遠隔成績および長期合併 症に関しては今後の問題点である.

\section{9. クルドスコピーによる多囊胞卵巣治療の実際}

（秋田大学医学部産科婦人科学教室）

\section{福 島 峰子}

不妊症診療において多囊胞卵巣症候群の占める 頻度は高い. 本症候群は内分泌学的に特異な病態 を示し，その半数は Clomiphene によく反応するが 残りは楔状切除術が奏効する.

私共がクルドスコピー下に楔状切除し, 組織学 的に確認した本症候群 42 例の中 34 例 $(80.9 \%)$ が
手術後妊娠に成功した. 今回, 先ず私共の実施せ る多囊胞卵巣症候群の診断基準を示し，クルドス コピーによる楔状切除術の実際を述べる。

麻酔は仙骨麻酔で行い $0.25 \%$ Bupivacain を初 回 10〜20ml 注入し, 必要に応じて追加するが大 体総量 $30 \mathrm{ml}$ 位になる。，大きな血圧変動や呼吸抑 
制は認められなかった。 クルドスコピーで観察す るだけなら $\mathrm{S}_{1}$ までで充分だが，卵巣の外科的処置 を加えるため無痛域を $\mathrm{Th}_{10}$ まで広げた。このこ とは腹筋の弛緩を得るためにも効果があった。

私共の使用するクルドスコープは硬性，側視， 広角のもので, 同時に両側卵巣が観察出来る。 ダ グラス窩には 2 孔式のスコープと $5 \mathrm{~mm}$ 直径の鉗 子を挿入して行う。卵巣は出来るだけ腹側遊離縁 にて広範囲に被膜を除去した。問題になるような 出血は殆どなかった。電気焼却法は術後の排卵成 績が不良であった，楔状切除後排卵しないままで 経過すると内分泌学的背景が改善されない限り再 発を繰返す。従って私共は術後 2 力月は無処置で 観察するが，妊娠が期待出来ない時は積極的に排 卵誘発を試みるが，その際は術前有効でなかった 誘発法も術後はかなり有効である。

妊娠成立までの 期間は術後 1 年以内に 34 例中 25 例 $(73.5 \%), 1$ 年から 2 年の間に $17.6 \%$, 従っ て妊娠成功例の $90 \%$ 以上は 2 年以内に妊娠した。 その予後に関しては同一症例が繰り返して妊娠し た場合子含め, 正期産 23 例 (自然分婏 19 例，鉗 子分娩 2 例, 吸引分婏 2 例), 過期産 3 例, 早産 2
例, 流産 6 例, 妊娠経続中 7 例である. 流産は全 例高プロラクチン血症を認めた。早産の 1 例は clomid 投与後 1 週目に HCG 投与すると同時に人 工授精し，妊娠したが妊娠 36 週で早産した. もら 1 例は血中プロラクチン值が境界值で HMG-HCG 療法で四胎妊娠したが, 妊娠 26 週で早産した。こ の例は 3 卵性 4 胎で第 4 児が 生下時体重 $550 \mathrm{~g}$ の 男児で，多種奇形を合併した potter 症候群で出生 直後死亡した。他の児に異常は認められなかっ た。

本症候群では高プロラクチン血症が 合併し易 く，境界值を含めると $40 \%$ 位に及ぶ。 その際，排 卵誘発法など治療法の選択に際し出来るだけ楔状 切除術を優先させ，それもクルドスコピー下に行 党ば再発時繰り返し実施し易い。その後もBromocriptine などでプロラクチン分泌を抑制し，そ れで充分排卵誘発出来なければ clomid, HMGHCG 法など誘発法を併用し，その際卵巣過剩刺 激症候群や多胎妊娠発生に注意し，妊娠しても流 産率が高いので，その管理に充分注意すべきであ る。

\section{0. クルドスコピーによる手術}

（和歌山市）

\section{岩 橋 五 郎}

手術は芸術という言葉があるが，内視鏡術も芸 術といえないことはない。普通の手術でもパイオ ニアは，師匠はなかったに違いない，しかし，一 般の芸術家にも当今指導者もあり学校もあるよう に，内視鏡領域でも研究会があってもよい。ただ 内視鏡術は一般手術と違って自分で身をもって体 験しなければならない面もあり，一般手術よりも かなりかんたんにたよる面も多いので，やはりべ テランの方が事はスムーズに進み, 事故も少なく 成果も多い。昔から手術者を, 成書のとおりやろ らとしても出来ない未熟者, やろらとすれば自由 に成書通りできるベテラン，それに成書通り自由 奔放にしても決して失敗しない名人の三つに分け るが，内視鏡手術も同じことだろう。そのうえ，
婦人科内視鏡を行ら者は，内視鏡術者である前に 訓練された産婦人科医でなくてはならない。内視 鏡のみの専門家は，えてして独善に抢ちいりやす く自慰になりやすい。内視鏡術のむつかしいとこ ろである。ささて クルドスコピーは穿刺事故はき わめて少く，もっとも臨床家むき開業医むきの骨 盤鏡で，オフィスラパロスコピーといわれるが， ラパロスコピーにくらべ，多くのディリットのあ るのは衆知のと拈りである。しかし，外科医ので きない経腟操作は産婦人科医の特技であるのに, 最近のように 経腹壁に行うラバロスコピーが主流 となったのは，自ら産婦人科の特権を放棄したよ らなものだ。しかも技術や器械の改善によってか なりの欠点がカバーされ, 残った欠点とラバロス 
コピーの事故発生率と考㝋わせればそのディリ

ットも相殺される.

もともと内視鏡検査は診断がその本来の目的で あり，それによって適確な治療法を決めることが できるのが真の姿であるが，視診中に小手術を施 すに足る所見があればその小手術が患者に与える 影響がきわめて少いといら立場から敢行すべきと 思う。しかし，内視鏡手術が開腹術の効果にとっ てかわるとは到底考兄られず不妊を主訴とした内 生殖器の根治手術にはなじまない. クルドスコピ 一手術の目的はラバロスコピーのそれと全く同一 であるが簡単な所感をのべると,

(1) 視診のみではなく，できる限り生検を行い， これによって視診以上の確診がえられ, 治療 効果をあげる事が出来る.

(2) 子宮広靶带の後壁に癒着した卵巣の剥離は

$$
\text { クルドの方がやりやすい. }
$$

(3)卵巣腫瘍の穿刺や内容除去の際内容を腹腔 内に残してはならない。

(4) 卵管采の非交通性遮断は癒着剥離をおこな えば時に妊娠に成功するので，開腹術の予行 として行って意味がある。

(5) 卵管楔状切除は開腹術によって行った場合 よりも，排卵誘発ひいては妊娠成功率も低く 自然排卵の持続期間も短いように思う。

内視鏡手術は，これを行ら事によって，開腹手 術とほぼ同様の効果をあげられる場合，又内視鏡 手術を行ら事により僥倖にも稀に，その目的を劇 的に達せられるよらな場合のみに限られる。少な くとも内視鏡手術を施行して患者に根治手術を行 なったよらな印象をおこさせてはならないと思 ら.

\title{
101. 群馬大学産科婦人科学教室における腹腔鏡施行例の検討
}

(群馬大学医学部産科婦人科学教室)

\author{
系賀俊一・谷口雄一・重城利国 \\ 五十嵐 正 雄
}

今回我々は 1978 年より 1981 年の 3 年半に於い て当教室で施行した 89 例の腹腔鏡検査について 検討しました。不妊症関係 42 例で大半が双合診 で内膜症の疑いをもたれた患者で 36 例であった. そのらち内膜症の存在しなかったのは 4 例であ り, 残り 32 例には程度の差はあったが, 内膜症病 巣が確認された。婦人科関係 42 例では無月経患 者が 24 例を占めており, 卵巣性無月経 12 例, 性 器閉鎖を伴ら例 8 例, ターナー症候群 3 例, PCO 1 例であった。卵巣性無月経 12 例では全例組織 診施行し原始卵胞を認めた例は存在しなかった。 又形態的には索状型低形成型が多かった．胵閉鎖 症を伴う例の内性器所見では種々の異常が存在
し，中には片側の卵管卵巣を欠除するという珍し い症例も存在した。 その他の月経困難症, 下腹部 腫瘤, 非定型子宮外妊娠, 原因不明の下腹痛など に腹腔鏡検査を施行したが，これらの症例では腹 腔鏡の有効性が再認識された。 89 例中副作用は腹 膜外気腫 4 例, 子宮穿孔 1 例であったが， 1 例で は腹腔鏡検査を途中で中止したが，開腹して腹壁 と腸管の癒着を見いだした例であり，腹腔鏡の適 応には注意が必要であることを痛感した。

当教室では腹腔鏡検査は年々増加しており, 日 常診療上欠くことのできない検査になっており， 今後さらに対象が拡大されてゆくよらに思われま す. 


\title{
102. 最近われわれの経験した腹腔鏡の症例について
}

（東北大学医学部産科婦人科学教室）

長池文 康 - 星 合 昊 - 星和彦
鈴 木 雅 洲

我々は，2・3 年来，主に不妊症の診断の目的 で腹腔鏡検查を行なっている. 今回は不妊症に限 らず腹腔鏡にて診断のついた子宮外妊娠，子宮穿 孔，双角子宮例と，子宮内膜症例について報告す る.

《症例 $1 》 32$ 才, 1 妊 0 産, 最終月経昭和 $\square$ 年

月曰日より 6 日間, 妊娠 7 週にて妊娠反応陰性 となり, 子宮内容清掃術を施行するも内容物なし. その後も性器出血, 下腹部痛が続き, 子宮外妊娠 の疑いにて当科紹介された。

Laparoscopy では右卵管狭部に 血腫様の腫瘤を 認め, 腹腔内に軽度の出血を認めた。開腹術を行 い，右卵管を切除した。

《症例 2 》19歳, 1 妊 1 産, 産裖 1.5 力月で性 器出血あり某医にて加療をらける。 2 週後再出血 し，子宮内容清掃術を行なったところ，大網様の 内容物あり, 子宮穿孔の疑いにて当科紹介された.

Laparoscopy では子宮前面やや右側に腸間膜の 癒着があり, 色素通水にてその部より色素の漏出 を認めた。開腹にて 約 $1.5 \mathrm{~cm}$ の穿孔があり縫合 術を行なった。
《症例 $3 》 32$ 才, 1 妊 0 産, 昭和 $\square$ 年口月, 自 然流産後妊娠せず，不妊症の治療をうけていた。 昭和口年口月某医にて HSG を行い単頸単角子宮 様であり, 確診のため当科紹介された。

Laparoscopy では双角子宮であり，左右子宮角 は浪涪同じ大さざあった。左右卵巣，右卵管は 正常であった。左畉管は軽度の水腫状であり，ま た狭部は索状となり細くなっていた。

《症例 4 》21 才, 0 妊 0 産, 月経困難症にて 来 院. 対症療法にて経過をみるも軽快せず，子宮内 膜症の疑いにて Laparoscopyを行なった.

Laparoscopy では，子宮・卵管・卵巣は正常であ った。 Douglas 裔はほぼ全面にわたり, 出血を伴 なう Endometriosis の implantを認めた。検査後 Danazol $400 \mathrm{mg} / \mathrm{day} 4$ 力月間投与し, 投与終了後 12 日目に再び Laparoscopyを行なった. Douglas の implant はほぼ完全に消失しており，帽針頭大 のらす茶色の痕跡を数個認めるのみであった，服 用終了後現在 3 週目であり, 今後の経過を追跡す る予定である。

\section{3．東海大学病院における腹腔鏡実施症例の検討}

\author{
(東海大学医学部産科婦人学教室産) \\ 井上正人・村上優 上黒島義男 \\ 藤 井 明 和
}

昭和 50 年東海大学病院が 開設されて 以来産婦 人科で施行された腹腔鏡検查は昭和 56 年末で 169 例に達したので，その成績を報告する。

内視鏡は昭和 56 年よりオリンパス社製の 針状 腹腔鏡を使用している。針状腹腔鏡の利点は直径
が $3.4 \mathrm{~mm}$ で, 皮膚切開は約 $5 \mathrm{~mm}$ ですみ, 切開創 を縫合する必要のないこと, Second lookなどにも 手軽に使えること，である，一方欠点はやはり視 野が狭いこと, 写真の解像力が悪いこと，であ る. 患者の入院は 3 日間で検査の翌日退院させて 
いる。

年度別に腹腔鏡検査数を見ると, 昭和 55 年まで は比較的少ないが，昭和 56 年になって急激に增え ている(表 1 )。適応は不妊症が 104 例(61.5\%) と 最も多く，外妊の疑いは 25 例 $(14.8 \%)$ とむしろ 少ない(表 2 ).

表 1 年度別腹腔鏡実施数

\begin{tabular}{|c|c|c|c|}
\hline 年度 & 手術総数 & 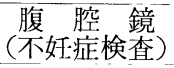 & 頻 度 \\
\hline 50 & 125 & $2(0)$ & $1.6 \%$ \\
\hline 51 & 313 & $5(2)$ & $1.5 \%$ \\
\hline 52 & 322 & $15(8)$ & $4.6 \%$ \\
\hline 53 & 409 & $27(10)$ & $6.6 \%$ \\
\hline 54 & 379 & $23(14)$ & $6.1 \%$ \\
\hline 55 & 437 & $29(18)$ & $6.6 \%$ \\
\hline 56 & 411 & $68(52)$ & $16.5 \%$ \\
\hline 計 & 2,396 & $169(104)$ & $7.0 \%$ \\
\hline
\end{tabular}

表 2 腹腔鏡検査の適応

\begin{tabular}{|c|c|}
\hline 不 妊 症 & $104(61.5 \%)$ \\
\hline 外妊の疑い & $25(14.8 \%)$ \\
\hline 付属器腫瘤 & $17(10.0 \%)$ \\
\hline 下 腹 痛 & $14(8.3 \%)$ \\
\hline 奇 形 & $6(3.6 \%)$ \\
\hline その他 & $3(1.8 \%)$ \\
\hline & $169(100.0 \%)$ \\
\hline
\end{tabular}

表 3 不妊症 104 例の分類

\begin{tabular}{l|r}
\hline 機能性不妊 & $48(46.2 \%)$ \\
卵管疎通障害 & $30(28.8 \%)$ \\
子 宮内膜症 & $14(13.5 \%)$ \\
Second look & $8(7.7 \%)$ \\
排 卵 障 害 & $4(3.8 \%)$ \\
\hline & $104(100.0 \%)$ \\
\hline
\end{tabular}

不妊症の内訳は機能性不妊 48 例 (46.2\%), 卵管
疎通障害 30 例 (28.8\%), 子宮内膜症 14 例 (13.5 \%)の順であった（表 3 )。卵管疎通障害のうち, 腹腔鏡の所見之一致したのは 20 例 $(66.6 \%)$ に過 ぎな参った(表 4).

表 4 卵管疎通障害 30 例の腹腔鏡所見

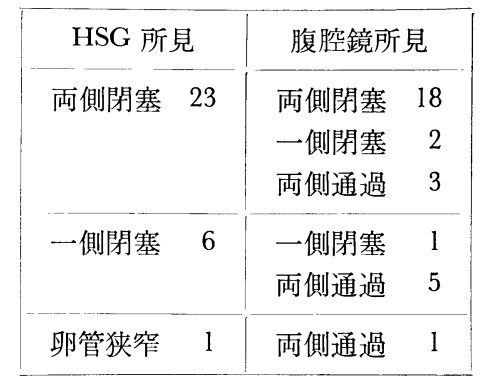

臨床的に内膜症と診断された 14 例は, 腹腔鏡で もすべて内膜症であったが， 3 例は軽症であった。 機能性不妊のうち腹腔鏡で骨盤内腔が正常であっ たのはわずか 10 例(20.8\%) で, 35 例 $(72.9 \%) に$ 子宮内膜症が認められた。このうち 32 例 $(91.4 \%)$ は軽症子宮内膜症であった(表 5 ).

\begin{tabular}{|c|c|}
\hline 子宮内膜症 & $35(72.9 \%)$ \\
\hline 軽 症 & 32 \\
\hline 中 症 & 3 \\
\hline 卵管采周团癒着 & $2(\quad 4.2 \%)$ \\
\hline 子 宮 筋 腫 & $1(2.1 \%)$ \\
\hline 正常 & $10(20.8 \%)$ \\
\hline & $48(100.0 \%)$ \\
\hline
\end{tabular}

腹腔鏡検查が骨盤内病変の診断，特に不妊症の 診断に有効であることは, 繰返し指摘されている. 今回のデータでも，卵管性不妊の診断には HSG の他に腹腔鏡検査が必要であること, 機能性不妊 のかなりの部分に子宮膜症が見られることが再確 認された。 


\title{
104. 腹腔鏡簡易ガス送入手技について
}

\author{
（名古屋市 可世木病院） \\ 可世木 辰 夫
}

内視鏡は現在あまり使われていない，設備に経 費が必要で，しかも収入につながらない所に一因 があると思われる.腹腔鏡のガス送入については， 全く経費のかからない方法を選ぶことができる.

送入ガスについては空気，炭酸ガス，酸素，笑 気が考えられる。水に対する溶解度は炭酸ガス> 笑気>酸素>空気の順で, 術後吸収度の高いもの が安全度が高くなる。

ガス送入で最も危険度の高いのは空気針の事故 である、空気針の安全栓子を入れたまま針を進め ると，針先は後腹壁に近づいてから前腹膜を破っ て突進するので，後腹壁に接触して危険である. 少量の炭酸ガスは炭酸カルシウム又は重曹と塩酸
で作ることができるから，中瓶に入れておき，こ れにガートルから水を送って，ガスを腹腔に送入 することができる. 水位 $1 \mathrm{~m}$ で注入すると $40 \mathrm{mmHg}$ 前後の圧が得られる.

このガス送入管の途中に三方活栓を置き，血圧 計をつなげば腹中気圧が測定できる，麻酔器には ボンベの気圧計と, 流量計があるから, 麻酔器の 笑気を炭酸ガス管と交換すれば，ガス送入器の機 能は一応備わったことになる。

完備したガス送入器では流入速度の制限と腹腔 圧の自動調節があるが，これは患者の反応に注意 していれば異常を察知することができる.

\section{5. 排卵障害患者のホルモン值と卵巣形態}

\author{
(川崎市立川崎病院産婦人科)
}

福田俊子. 高橋正明 - 中 村英世
岩 田嘉 行

排卵障害患者の卵巣にはいくつかの特徴的な形 態を示すもののあることが知られており，その把 握は誘発方法の選択に際して有用であるとされて いる。我々は，排卵障害に起因する不妊症患者に は, ルーチン検查の後, 誘発を行ら前に腹腔鏡を 行い卵巣形態の観察を行なっている。卵巣形態と 尿中および血中ホルモン值との関係については統 計学的検討を加光, 第 26 回不妊学会総会において 報告した。 今回は症例を追加することが出来たの で，逆にホルモン值からその患者の卵巣形態を把 握できるかどらかを検討した。

対象は 1973 年から 1982 年 1 月までの間に当院 で腹腔鏡を行なった排卵障害患者 92 例のうち, 当 院の分類基準に従って両側とも同じ形態を示した
71例についてホルモン測定值を比較した。71例の 内訳は, PCO 型 28 例, 硬化型 4 例, 萎縮型 4 例, 発育不全型 12 例, 非特異型 23 例であった。

尿中 17-KS では, PCO 型が明らかに高值を示 し, 硬化型, 萎縮型, 発育不全型との間に有意差 (P>0.05)がみとめられたが，PCO 型と非特異型 とでは有意差はなかった。尿中17-OHCS は PCO 型にやや高值のものがあるが相対的に排卵障 害者の尿中 17-OHCS は正常範囲内か, やや低い 傾向にある，血中 FSH はPCO 型, 非特異型でや や高值を示すものがあり, 発育不全型では, 低い ものと異常高值を示すものと 2 群に分れる傾向に あり，平均でみると，PCO 型と発育不全型では $\mathrm{P}>0.05$ で発育不全型が 高值であった。 血中 $\mathrm{LH}$ 
は, FSH と同様発育不全型で低值を示すものと異 常高值を示すものがあり，他の形態においてはい ずれも高值であり，有意差はなかった， FSH/LH では, 発育不全型が, PCO 型, 非特異型に比して 大きかった $(\mathrm{P}>0.05)$. 血中 $\mathrm{E}_{2}$ では $\mathrm{PCO}$ 型, 非 特異型で $100 \mathrm{Pg} / \mathrm{ml}$ をこえているものがあるが, 他は大部分 $100 \mathrm{Pg} / \mathrm{ml}$ 以下であった。しかし統計 学的に有意の差はない. LH-RH テストに関して は, 症例の少ない硬化型, 萎縮型を除くと, FSH では発育不全型に前值, 頂值ともに高いものが多 く, LH では PCO 型で頂值の上昇が発育不全型, 非特異型よりも高かった。

以上，ホルモン值の平均值を比較することによ り，いくつか卵巣形態別特徵をみいだすことは出 来るが, 各ホルモン值の分布が示すように, その
分布は一様ではなく特に LH に関しては, 同一ホ ルモンでも变動がかなりあることから，ホルモン 值から，その患者の卵巣形態を把握することは非 常に困難であると考えられる。例えば，PCO型に ついて 17-KS $8.1 \mathrm{mg} /$ day 以上, LH $20 \sim 40 \mathrm{mlIU} / \mathrm{ml}$ といら二つの条件を仮にあてはめてみると, 症例 のらちこの条件を満たしたものは 8 例で, 4 例の 又が $\mathrm{PCO}$ 型で，適中率は $50 \%$ となる。 しかもこ れは両側とも $\mathrm{PCO}$ 型であった 19 例に対してわず か $20 \%$ に過ぎない，従って我々の経験では，ホル モン測定值のみで卵巣形態を推察するにはかなり の困難があると考劣る。

やはり，排卵誘発法の選択などに関しては, 腹 腔鏡にての観察がより臨床的に有用であると思わ れる。

\title{
106. 腹腔鏡所見としての萎縮性卵巣の内分泌的背景
}

\author{
（川崎医科大学附属川崎病院産婦人産）
}

田中良憲・山崎典子

昭和 51 年 6 月〜昭和 56 年 12 月までに当科不 妊外来を訪れ，腹腔鏡検査を行なった 244 例中， 腹腔鏡所見より萎縮性卵巣と診断された 5 例と, 試験開腹により萎縮性卵巣と診断された 1 例を対 象として萎縮性卵巣の内分泌的背景につき検討し た.

\section{《結果》}

(1) 月経異常の型

6 例中, 5 例は続発性無月経 II 度, 1 例が無 排卵周期で原発性無月経の症例はなかった。

(2) 尿中エストロゲン

全症例低值で卵巣機能の著しい低下を示し た.

(3) ゴナドトロピン

Hypergonadotropin は 3 例で, LH-RH テス トは hyper good responce. Hypergonadotropic は 2 例でLH-RH テストは poor responce. Normogonadotropic は 1 例で LH-RH テストは good responce.
(4) 排卵誘発剂に対する反応 normogonadotropic 91 例が clomid + VitC, PMS + HCG, HMG + HCG で有効. HypogcNadotropic $の 1$ 例で clomid + HCG が有効. 他 は無効であった.

\section{《考察》}

萎縮性卵巣の内分泌的背景は, hypergonadotropic な卵巣原発の卵巣萎縮と, hypogonadotropicな 二次的な卵巣萎縮の両者がふくまれていると思わ れる. 各種の排卵誘発法に対しては反応し難く, 特に hypergonadotropic なものは, 他の normogonadotropic, hypogonadotropic なものに比し, 反応 が悪かった.

このように, 内視鏡で萎縮性卵巣と診断された ものを, さらに内分泌的背景を検査することによ り,これを hypergonadotropic, hypogonadotropic に 分類でき，これは排卵誘発法や，効果を知るため に有用な指標となり得ると考乓る。 


\title{
107. Endometriosis に対するDanazol 治療における 無効例または改善の悪い症例の検討
}

（名古屋市立大学医学部産婦人科学教室）

\author{
小 池 皓 式 三 村 三喜男 - 八 神 喜 昭
}

最近 17- $\alpha$-ethinyl testosterone の誘導体であるDanazol(isoxasol ethisterone) が下垂体を介して卵巣ス テロイド産生を抑制し，子宮内膜を萎縮，壊死さ せる強い作用をもっている事がわかり, 臨床的に も子宮内膜症に対する有効性についての報告が多 ᄂ.

しかしながらこの Danazol の有効性の報告は 多いが，無効例等の検討が充分なされた報告は少 ない. 今回, Danazol の臨床報告と共に, Danazol 無効例又は改善傾向の少ない症例のうち, 開腹手 術した 1 症例について報告する。

この症例は, 以前より月経困難症が強く, 53 年 に開腹手術を某医にて受け，外性子宮内膜症の診 断にて, 一側の付属器切除術並びに他側の癒着剥 離術をした。 その手術後, 月経困難症は以前より 増強し, 月経時以外も下部疼痛並びに腰痛も著明
で，当科を受診した．子宮内膜症にて腹腔鏡を行 なったところ, Beecham 分類にて $\mathrm{N}$ st にて, ゲス ターゲン治療 8 力月間, 偽妊娠療法を施行するも 軽快せず，Danazol $400 \mathrm{mg} /$ dayにて 6 力月間連続投 与するも, 症状の軽減注とんどみられず, 患者の 希望も強く，開腹し子宮の摘出を行なった。 その 手術所見としては, 小骨盤腔内の強度の癒着あり, 一部内膜症所見あるも, 膜状の痖着も強く, 特に 子宮を中心に癒着していた。更に，その組織所見 にて，子宮には腺筋症の所見を強く認めた.

なおこの症例以外にて，開腹手術した Danazol 無效例又は改善の徳い症例にも, Adenomyosis の 所見が涩められた。これらの症例の如く, Adenomyosis 合併の 外性子宮内膜症例では Danazol 投 与にて軽快しない例が多いと考えられた。

\section{8. ビデオシステムによる内視鏡手術手技}

\author{
(鳥取大学医学部産科婦人科学教室)
}

岩浅義 楌

内視鏡手技は従来のただ単に腹腔内を観察する ことから，内視鏡を使った手術を行ら段階へと進 歩している.

内視鏡手術の施行に打いては，様々な鉗子等を 使用する必要性から，テレビの画像を見ながら手 術手技を行らといらビデオシステムを利用すると 容易かつ安全に手術が終了できる.

我々はビデオシステム下の内視鏡手術手技, 主 として腹腔鏡下の各種不妊手術を行なったので, その内容について報告する。

《方法》NLA 麻酔および 局所浸潤麻酔下にて,
自動気腹器にて人工気腹を行い，次に套管針外套 管を刺入し，套管針を抜去したのち，腹腔鏡を挿 入する。腹腔鏡と同じ場所より各種卵管鉗子を插 入する。 二孔式では恥骨上窩より各種卵管鉗子を 插入し，そののちビデオシステム下にて各種術式 を施行した。卵管操作終了後, 腹腔鏡および各種 卵管鉗子を抜去し手術を終了した。

《成績》米国の大学で施行した症例预よびビデ オンステムによらない従来の手術法によるものも 含めて, 双極性凝固法 229 名, シリコンバンド法 130 名, スプリングクリップ法 2 名に不妊手術を 
施行した.

《結論》従来の方法と比較してビデオシステム
下では各種手術術式の操作が容易にでき, 安全に 施行できた。

\section{9. $\mathrm{CO}_{2}$ Hysteroscopy と Fluid Hysteroscopy の比較検計}

(秋田大学医学部産科婦人科学教室)

関 守利 · 関

〔目的〕日本では一般に $\mathrm{CO}_{2}$ Hysteroscopy の短 所が強調され，臨床では殆ど使用されていない. 一方西ドイッでは $\mathrm{CO}_{2}$ Hysteroscopy が使用され, Fluid Hysteroscopy の短所が強調されている。 それ ぞれの国で，その样な Hysteroscopy に関する状況

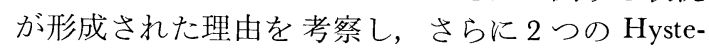
roscopy の優劣を明らかにし, 今後の臨床に結びつ けていくために, 本検討を行なった。

〔方法〕日本と西ドイッで行なった Fluid Hysteroscopy と, 西ドイッで行なった $\mathrm{CO}_{2}$ Hysteroscopy について, 操作, 視野の明確さ, 診断について比 較した。 最近 Hysteroscopy の出血を訴える患者に おけける有用性が高まっているため, 不正出血を訴 えた 142 例の閉経前婦人の Fluid Hysteroscopy, 48 例の閉経後の婦人の Fluid Hysteroscopy，また西ド イッで不正出血を訴えた 52 人の患者に関しての $\mathrm{CO}_{2}$ Hysteroscopy 所見について, 詳細な比較を行 なった。

〔結果及び考察〕視野の明確性, 写真による記録 性については $\mathrm{CO}_{2}$ Hysteroscopy が優っていた。 器 械装着, 操作の簡便性では Fluid Hysteroscopy が 優る. $\mathrm{CO}_{2}$ Hysteroscopy は付属装置により, control され, 習熟しない者が扱っても危険が少ない. 播種の危険性に関しては $\mathrm{CO}_{2}$ Hysteroscopy がやや 少なく, 不妊患者の診断に関しては, $\mathrm{CO}_{2}$ Hysteroscopy が最適である.

出血を訴えた患者の診断に関しては，142 例の 閉経前婦人の Fluid Hysteroscopy による所見では 悪性率が $6.1 \%$ で，観察不可の症例はなかった。 同椂に閉経後 48 人の婦人の症例では, 悪性率 41.7
美千子 - 福 島 峰子

\%で，観察不可の症例はなかった。 52 人の $\mathrm{CO}_{2}$ Hysteroscopy 所見は悪性率 3.8\%で，Myoma 患者 1 名において，非常に観察困難な経験をした。 54 年の日産婦総会に扣いて発表した。悪性所見の診 断基準に関する両者の比較においては，所見が子 宮後壁にある場合には, 微細な Surface pattern 及 び微小血管の観察時に $\mathrm{CO}_{2}$ Hysteroscopy では困難 を感じた。

西ドイッで Fluid Hysteroscopy に対する比判が 生まれたのは, 日本の現在の環流式が出現する以 前であった。 そのため, Fluid を腹腔内に押し入 れる可能性が高く, さらに液体の性質上血液と混 入し観察が難しいため, その時点で $\mathrm{CO}_{2}$ Hysteroscopy の優位を確信し，その中で診断技術を開拓 していったと考えられる。

一方日本では環流式がその後開発され，さらに 媒体も検討され当初欠点とされた Fluid の逆流, 視野の悪さも改善された。逆に $\mathrm{CO}_{2}$ Hysteroscopy も一定圧自動ガス注入装置の開発や, 出血に対し ては瞬間的 $\mathrm{CO}_{2}$ ガスふきつけや, biopsy管よりポ リエチレン管を插入して吸引除去するなどの工夫 をしている。ただし出血多量の場合は Fluid Hysteroscpy が優る.

両者とも，機械装置，診断手技に習熟すること により診断上はさほど支障をきたす症例はないと 考えるが，私的には Fluid Hysteroscopy が良いと 考学られるが，これは Fluid Hysteroscopy の少及 の優位性の上に，私が Fluid Hysteroscopy により 習熟しているためと考学る。 


\title{
110. 再びヒステロスコピー時の medium の比較
}

\section{（大阪医科大学産婦人科学教室）}

$\begin{array}{llllllll}\text { 後山 尚 } & \text { 久・宮 } & \text { 崎 } & \text { 和 } & \text { 典・神 } & \text { 田 } & \text { 隆 } & \text { 善 } \\ \text { 柚 木 } & \text { 孝 } & \text { 土伊 } & \text { 藤 } & \text { 正 } & \text { 尚・杉 } & \text { 本 } & \text { 修 }\end{array}$

子宮内視鏡の歴史は 1869 年に Pantaleoni が子宮 腔内を簡単な器具で観察し, endometrial polyp を 報告したことから始まり，100 年が過ぎた。その 間, 外套管やレンズ系あるいは光源が発達したこ とにより十分な視野が得られ，写真撮影も可能と なった. 最近の診断技術の向上とともにさらに正 確な所見が必要となり, そのためには上記の項目 以外にメディウムの検討が必要である. 我々は今 回, 生食, デキストラン $70, \mathrm{CO}_{2}$ ガスを種々の症 例に使用し, 比較検討を行なった。

子宮体癌では内腔への隆起は $\mathrm{CO}_{2}$ ガスが生食に 比べ観察しやすいが，悪性の判定に重要な血管の 所見が把握しにくい. 子宮笳腫や子宮内膜ポリー プなどの隆起性病変に関しても同様である. $\mathrm{CO}_{2}$ ガスでは柔軟な隆起性病変, 特に polyp, focal hyperplasia, cystic gland などでは腫瘤が子宮壁に圧 排され，その形状や大きさ，位置が変化すること がある。また $\mathrm{CO}_{2}$ ガスでは腔拡張圧が高いらえに メディウムの漏れが多く, 子宮内圧の調節に困難 を感じる，対物レンズに曇りを生じるという久点
も持つ、 $\mathrm{CO}_{2}$ ガスの利点は全体像の把握が容易で ある点と遠近感がつかみやすい点である.

メディウムの比較上, 最大の相違点で診断上重 要である, 細部の観察に関しては生食では容易で あるが，デキストラン 70 拈よび $\mathrm{CO}_{2}$ ガスでは困 難であり, 特に $\mathrm{CO}_{2}$ ガスでは不可能に近い. これ は高い腔拡張圧, 困難な内圧調節, 不十分な血液, 粘液除去, 光源の反射によると思われる. その他, デキストラン 70 や, $\mathrm{CO}_{2}$ ガスでは子宮内視鏡施 行中, 施行後に腹部不快感を認め, 欧米では $\mathrm{CO}_{2}$ ガス内視鏡による感染症や空気栓塞の合併症が報 告されている.

欧米では gas hysteroscopy が主流であり, 我が国 では liquid hysteroscopy が広く施行されている。 今回種々の点について，それぞれのメディウムの 比較をしたが, 病変部の観察条件の設定, 細部の 観察, 合併症などの点より, liquid hysteroscopy が gas hysteroscopy に比較し, betterであると考える. 中でも細部の観察の点から生食によるhysteroscopy が best と考える.

\section{Hysteroscopy 所見と HSG 所見の比較検討}

\author{
（秋田大学医学部産科婦人科学教室） \\ 福島峰子・関守利
}

不妊症の routine 検査の 1 つとして子宮卵管造 影が行われている。これは卵管因子に関すること は勿論頸管, 子宮, 骨盤腔内の情報を得ることが 出来る.しかしあくまで陰影から得る所見である. 子宮卵管造影(HSG) で子宮腔内の異常所見があれ ば，さらにヒステロスコピーで鑑別診断すること により不妊症, 不育症の子宮側因子をより正確に
診断することが出来る.

HSG による各種の子宮像には,

位置の異常, 大ささ, 奇形

子宮腔の弛緩, 変形, 影像欠損

壁の不整, 脈管像, 内子宮口の拡大

などがある.

今回はHSG に異常所見を得られた 12 症例のそ 
れに対応したヒステロスコピー所見を供覧した い.

症例 1。双角子宮十子宮下部のポリープ

" 2. ポリポージス

" 3 . 内膜癒着

" 4 . アッシャーマン外傷性癒着

" 5. 内膜癒着 + 脱落膜遺残

" 6. 内膜癒着 + 太田リング

" 7. 頝管狭窄 + cooper $\mathrm{T}$

" 8 . 帝切時の疲痕性狭窄十綟系

" 9 . 腺筋症

" 10. 右卵管口喤室

" 11. 内膜癌

"12. 内膜癌

HSG は病変部の子宮全体に対して占める位置,
子宮腔の変形など外廓を知るのにより有効であ り，ヒステロスコピーは内膜表面構造，色，血管 走行などを知るのにより有効であった。 ヒステロ スコピー実施時内膜組織診を行なっているがポリ ープや内膜癒着などは組織診よりヒステロコピー の方が診断され易く，筋腫や腺筋症はむしろ HSG の方が参考になる.

従って検査所見の背景を考えながら，HSGで Screening して影像欠損をヒステロスコピーで検 討し，狙い組織診をするということが正診率を向 上させるのに不可欠である。ただ HSG で Sereening 出来ずヒステロスコピーで発見出来る変化も あることも知るべきである.

最後に 各疾患の HSG およびヒステロスコピー 所見上の鑑別点をスライドにまとめた.

\section{2．子宮鏡を用いての粘膜下筋腫摘除術}

\section{（大阪医科大学産婦人科学教室）}

宮崎和典・後山尚久・神田隆善

柚木孝士・伊藤正尚 - 杉本修

当科では，子宮等腫の疑われる症例には，ルー チン検査法として, Hysteroscopy を施行しており, 一般の診断法では確診のつかない 粘膜下筀腫の発 見に努めている。 さらに有茎筋腫では, その腟式 摘除の可否をHysteroscopy 下に決定し, 良好な成 績を得ているが，その要領を実例をもって説明す るとともに，その際における注意点を述べる。

昭和 54 年 6 月より 2 年半の間に, 当科で子宮筋 腫の疑いにて Hysteroscopy を施行し, 何らかの筋 腫所見を示した 109 例のうち 粘膜下筋腫は 60(55 \%)であった。 そのらち 23 例( $38.3 \%)$ が有茎筋腫
で筋腫分婏例が 9 例含 まれていた。 23 例中 17 例 に腟式摘除を行ない, 全例合併症もなく, 良好な 結果であった。胵式摘除の適応例に拈ける Hysteroscopy 所見は, 腫瘤の大きさが $3 \mathrm{~cm}$ 大ぐらいま である事, pedicle が細く長い事, 柔らかい事など であった. 又 pedicle は切断しえても腔内より摘出 できず，頝管拡張術のような工夫が必要な例もあ った。 以上，粘膜下有茎筋腫の腟式摘除の際にヒ ステロスコピーを応用し，その有用性が示唆され るとともに，婏出方法の工夫によって腟式摘除の 適応範囲も広がるものと考劣られた。 


\title{
113. 胞状奇胎の予後追跡に対する内視鏡検查の応用
}

\author{
（大阪医科大学産婦人科学教室） \\ 神田隆善. 宮崎和典 - 後山尚久 \\ 柚木孝土・伊藤正尚 - 杉山 修
}

破壞性胞状奇胎の $95 \%$, 絨毛癌の $60 \%$ は胞状 奇胎を先行妊娠とし, 奇胎娩出後の厳重な管理に よっても約 $10 \%$ に続発性疾患の発生がみられる. 奇胎婏出後, 絨毛性疾患が疑われた場合, その多 くは first choice として, chemotherapy が行われる. その効果判定にはHCG の消長と原発巣(子宮) と 肺転移巣のX線像が重視されている。特に, 本症 の病態発生上の特異性より, 原発巣の変化は子宮 筋層内の状態をよく把握できる PAG が最も信頼 されている。教室では, さらに子宮筀層内外の状 態をより正確に知るため, PAG に加えて, hysteroscopy と laparoscopy を行い, 奇胎婏出後の管理 に応用している。 今回, これらの成績の一部を報 告する。

奇胎婏出は吸引搔爬術によって行なっている が, 再搔爬後でも hysteroscopy では mole や decidua の遺残がかなりの頻度に観察された。 さらに, 奇胎婏出後 7 カ月経過している症例に necrosis に 陷った decidua の遺残がみられた。このことから， 奇胎婏出の管理の前提となる子宮腔内に 奇胎遺残
が存在しないことを明確にする上で, hysteroscopy は不可欠である。また頻回に子宮内操作をらける ため Asherman's syndrome がみられるものが多い が, 術後不妊を防止するため, 発見しだいに癒着 剥離を行なっている。䄉毛性疾患が子宮腔内から 直視できるのはその病巣のごく一部であり, しか も特有な囊胞を認めることは少ない。しかし, PAGの異常院影々一致した子宮腔内への笳層隆起 は, その病状の鎮静化に伴い減少していき, 緩解 時には消失するのが観察された。

一方, PAGにより相当大きな hematoma が推測 される場合, 子宮穿孔の予知に laparoscopy は有意 義であり，さらに lutein cyst によると思われる高 HCG 状態や茎捻転の場合にも laparoscopy による cyst の内容除去が有用であった.

教室では肺転移例の手術適応を決定する場 合 に, 原発巣がコントロールされていることを確認 するため, 子宮腔内は hysteroscopy, 子宮笳層は PAG，子宮漿膜側は laparoscopyを行なって，その 判断基準にしている.

\section{Hysteromicroscopy}

(日本医科大学産婦人科学教室)

$$
\text { 大川公康 } \text { 大 } 川 了 \text { 氿 }
$$

子宮鏡検查は子宮内を直接観察して診断する方 法であるが, 光源や光学系の進歩によって拡大観 察が可能になった.

[方法〕

使用器具は町田製 PAN-Endomicroscope で，直 視型と側視型がある。これはアダプターリングを つけたオリンパス OM-2 を用いて撮影するとフイ
ルム面で約 200 倍の像が得られ，これをサービス サイズのプリントにすると約 800 倍となるので, 細胞，核の異型は容易に観察された。

更に Stortz 製の Contact Microhysteroscope を用 いて観察した。これは 2 倍のコンバーターを用い ても 80 倍の像がフィルム面で得られるので細胞 レベルでの観察は不充分である。 
細胞核の超生体染色が必要である。これにはク レシールヴィオレットアセタートを用いた。 アル コール飽和液を 10 倍に稀釈して用いる. チオニン の飽和液を $10 \%$ に加えた。これは DNA を特に染 色するためである。

〔成績〕

(1)正常の子宮内膜には異型血管や血管の拡大は 見られなかった。

(2)子宮内膜の hyperplasia は40 例で，特に異型 のなかったもの 15 例, 肥大と診断したもの 12 例, 異型( 1 度) と診断したもの 12 例であった。

(3)内膜癌の場合は 23 例中 21 例に異型 II 度と診
断した。

(4)額管内の異型上皮, 上皮内癌の判定に有用で あった。

(5)異型血管については 30 倍拡大の Storz の Contact Microhysteroscope が有用であった。これは直 径 $4 \mathrm{~mm}$ であるので插入が容易であって 血管の異 型をみる場合は更に町田製の PAN-Endo-Microscopeで観察している.

〔結論〕

細胞レベルで観察する事は内視鏡の分野で重要 な事で, 組織所見の観察前に悪性, 良性の判定が 可能である.

\section{5. 第 1 回国際内視鏡学会 (マイアミ)に出席して}

\section{(大阪医科大学産婦人科学教室)}

福田吉彦

昭和 57 年 1 月 $3 \sim 6$ 日, アメリカ 合衆国, フ ロリダ州. マイアミビーチ, The Fontainebleau Hilton Hotel において, AAGL(American Association of Gynecologic Laparoscopists) 主催により, Jordan M. Phillips を General Chairman として First World Congress of Hysteroscopy が行なわれました。

我国からは，本学杉本教授の Diagnosis of Endometrial Cancer by Hysteroscopy, Diagnostic and Therapeutic Hysteroscopy for Asherman,s syndrome 及び 日本医大大川教授の Hysteromicroscopy の 3 題が出 されました。

基礎分野では, 子宮拡張の方法物質として $\mathrm{CO}_{2}$, saline あるいは Dextran70 のそれぞれの 比較検討
がなされました。不妊の分野では Asherman,s syndrome の診断と治療, 避妊の分野では silicone を 用いた tubal occulusion method についての演題が 数題ありましたが，いまだすぐれた成績は得られ ていないようでした。腫瘍の分野では, endometrial cancer の診断が主な論点となりました. 他の 演題では Hysteromicroscopy，特に生体染色を用い て診断に役立てるという topic な演題がありまし た.

学会期間中を通して活発に討論がなされ，盛 りあがった学会となりましたが，我国からは演題 が 3 題しか出されなかったのは寂しく思われまし た. 